\title{
Adaptive Reuse of Historical Safavid Caravanserais in Iran as a Sustainable Development Strategy
}

\author{
Ahmadreza Saberi $^{1 *}$; Anuar Talib ${ }^{1}$; Shervin Motamedi $^{2}$; Shahab Kariminia $^{3}$ \\ ${ }^{1}$ Faculty of Architecture, Planning and Surveying, UiTM, Shah Alam, 40450, Malaysia \\ ${ }^{2}$ Department of Civil Engineering, Faculty of Engineering, University of Malaya, 50603, Kuala Lumpur, Malaysia \\ ${ }^{3}$ Faculty of Art, Architecture and Urban Planning, IAU University, Najafabad Branch, Isfahan, Iran
}

Email: saberi.ahmadreza@gmail.com

http://dx.doi.org/10.18415/ijmmu.v3i3.41

\begin{abstract}
A large number of caravanserais were built during the Safavid era in Iran. However, due to the natural effects and human neglecting actions they are going to be ruined. Adaptive reuse of Safavid Caravanserais can be considered as one of the possibilities to preserve them from being demolished. The present study intends to categorize caravanserais based on the diversity of Iranian geographical and climatic zones as well as their distances from urban centers to determine their potential for adapting reuses. Since several of caravanserais still possess a characteristic building plan to accommodate travelers and are capable of retaining their functional elements, adaptive reuse can be applied. Therefore, the decision to reuse some of the buildings as hotels or restaurants seems rational.
\end{abstract}

Keywords: safavid caravanserais; adaptive reuse; sustainable development

\section{Introduction}

Integration of interdisciplinary sciences is not a recent issue, particularly where an important concept such as sustainable development is concerned. Islamic architecture has been studied extensively by researchers (Haji, 2007; Hillenbrand, 1994; Rabbat, 2012); however not many researchers have considered the idea of combining modern construction techniques with the existing abandoned historical building. Some of the methods that can be used would restore, preserve and renovate existing historical buildings which are not in service at the moment but which can be used for their historical value (Bullen, 2007). Nevertheless, the adaptive reuse of historical structures is an approach that has been used for developing historical areas, and consequently, the existence of the buildings is guaranteed (Morton, 1997). In this study, the types of Safavid caravanserais and their distances from urban areas, followed by their possibilities of their adaptive reuse projects have been considered. 
The Safavid dynasty (1502- 1722), was one of the most triumphant eras of Iranian history from the time of the Islamic conquest of Persia (Babayan, 1994). Commercial routes were common during the Safavid era to connect Iran to other countries. Travelling caravans required a safe route that provided shelter from the brutality of nature as well as bandits and to make travel more convenient when the time to rest came (Abisaab, 2004). Therefore, hundreds of new caravanserais were constructed by the order of Abbas the Great (Born 1571, died 1629). Furthermore, according to the geographic location and climatic condition of Iran, caravansaries' plans are different in terms of architectural patterns. This paper aims to find the most appropriate strategy with regard to their conservation and sustainable development of these historical buildings.

\section{Function of Caravanserai}

There is a generally accepted reason why rulers built caravanserais. The background of Silk Route is not clear but Boulnois (2004) mentioned that this route was used from around 2000 B.C. It was started in China and the destination of this road was Turkey. Usually these kinds of historical building were built every 30-40 miles along the route. Caravanserais were built by powerful rulers who wanted to encourage traders because safe places could bring in more merchants and subsequently more money. Rulers collected tax from traders and therefore they intended to keep trade routes safe and open. The kings of Safavid absolutely knew the importance of Silk Route and thus ordered to construct around 1000 Caravanserais either small or large in all the way of roads inside the boarder of Iran. They were built the places which called them caravanserai in rural, semi-rural and urban areas. Nowadays, after around 500 years, they were destroyed by human actions or natural disasters.

Hillenbrand (1994) in his book noticed that the caravanserai is the largest type of Islamic building. Furthermore, he expressed that in the harsh conditions, merchants and pilgrims needed frequent places of rest; places where men and their animals would be safe for the night, and where they could be sure about the existence of food and water.

About the financial source to build a caravanserai, Hillenbrand (1994), reported that enough inscriptions have survived on the entrance of caravanserais to clarify the name of the patronages which spent money on building caravanserais. The aim was to collect tax from travelers. However, majority of caravanserais were constructed by the order of sultans and thus they were built on the governmental fund. Compare to national caravanserais, the private ones were not large in quantity. It also must be stated that these buildings were mainly complemented by defense towers and armies in order to protect merchants and building from bandits.

\section{Categorization of Caravanserais Based on Climatic Zones}

Rabbat, (2012) claimed that during Safavid era caravanserais were built in three different types according to the geographical zones.

\subsection{West Area Caravanserais: Cold Areas}

A common plan of cold area caravanserais was consisted of a central covered residence and a series of small rooms along with surrounded stable behind the rooms (Figure 1). Any courtyard did not exist but caravanserais had a wide and central hall for dwelling travelers. Majority of mountain caravanserais had many chimneys in building. These kinds of caravanserais were covered by all sides because they must 
protect travelers from cold winds, rainfalls, snows and hailstones (Andaroodi, Andres, Einifar, Lebigre, \& Kando, 2006).

According to the function of this type of caravanserais which was keeping travelers in a warm place, were; the height of ceiling was not too high because of providence in using wood or coal to make fire; and putting stables spaces between traveler's dwelling room and outdoor of caravanserais due to making rooms warm. And the last point was, use of stone instead of brick, because stone can keep warm air inside rooms more than bricks.

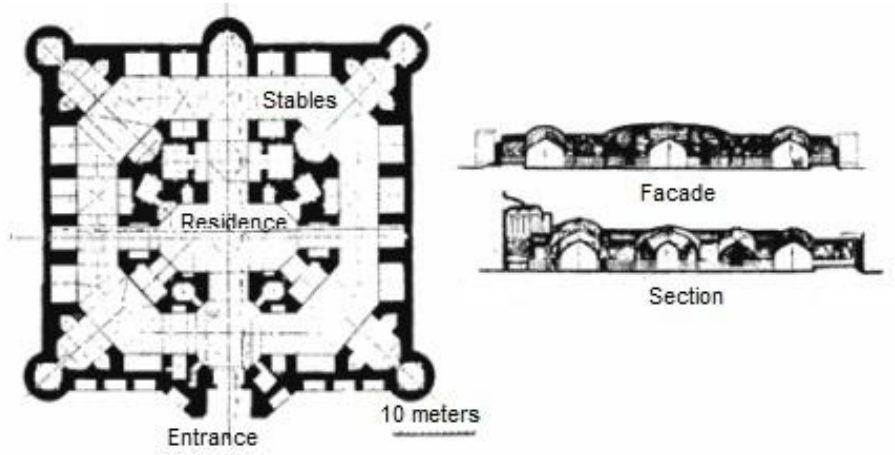

Fig. 1. A sample of cold area caravanserai plan; Shabli caravanserai (around 1620 A.D)

\subsection{South Area Caravanserais: Warm Areas}

Due to the warm weather in that area, caravanserais also were built in unusual and varied plans. They did not have any open courtyard but the designer supplied many ways for air ventilation such as windows and arches (Figure 2). They normally were formed in square plan following by a cross central room for travelers and corner rooms as animal stables. The building is usually built on a stone platform. These types of caravanserai did not have any military defenses structure because they were built during peace time, so they did not need many protection elements.
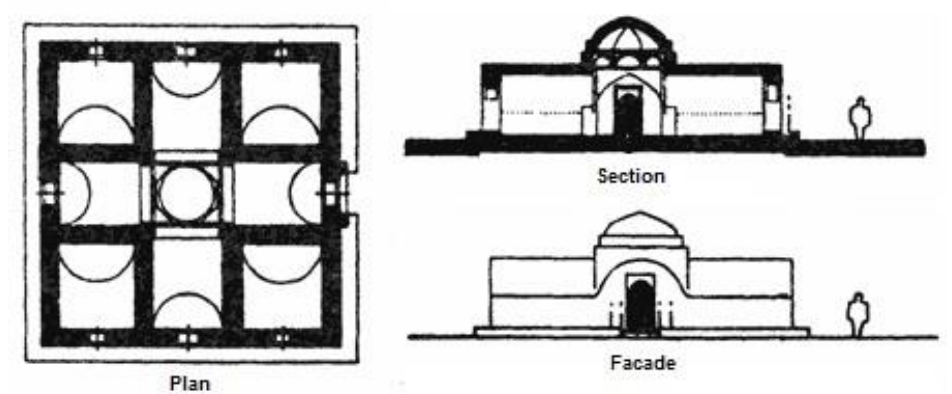

Fig 2. Yungi caravanserai, an example of caravanserai located in the warm area (around 1610 A.D) 


\subsection{Central Area Caravanserai}

The majority of Iranian caravanserais are located in the center of Iran which are mainly intact and more suitable for adaptive reuse. Majority of them have a special plan with courtyard in the middle and rooms are arranged around it. It is also known as "introvert planning". They commonly have four Iwans which are emphasized by large arches. An example of four Iwans caravanserai with a central courtyard is demonstrated in figure 3.

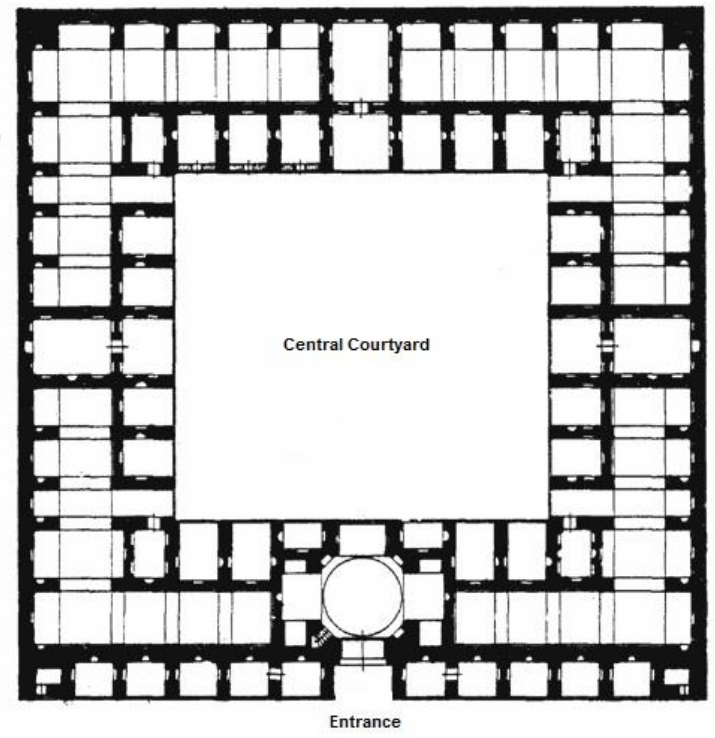

Fig 3. Boqm caravanserai, located near Isfahan city, Safavid era; (around 1600 A.D)

\section{Classification of Caravanserais with Regard to Urbanization Distance Diversity}

Any sustainable development plan must be accompanied by a management system. The manager must determine the requirements of a site by considering the location and how the area should be developed (Kianmehr \& Taghvanejad, 2011). In this regard and to make an explicit point of view, caravanserais can be divided into three main groups; Urban caravanserais, Semi-urban caravanserais and Rural caravanserais.

\subsection{Urban Caravanserais}

Urban caravanserais which are combined with bazaars, had different plans compared with rural or semi-urban caravanserais (Haji, 2007). Unfortunately, information about urban caravanserais is quite insufficient as a result of urban developments in cities. City caravanserais had to be designed to accommodate shopkeepers and merchants on a permanent, instead of merely temporary, basis. Parameters that made up the differences between the urbanization features between caravansaries were: size, chronology, materials, plan, decoration, construction techniques and the range of facilities. 
Figure 4 and Figure 5 depict one of the finest instances of Safavid urban caravanserai, the Chahār $B \overline{a g h}$ complex building. This multi-functional building includes a mosque, caravanserai, bazaar and religious school (Pearson \& Sullivan, 2013; Worthing \& Bond, 2008). The old caravanserai part of this complex has been successfully adapted for reuse as a hotel since 1968. However, the other parts such as the bazaar, religious school and mosque have retained their original role but several conservation and renovation projects have been carried out on them.

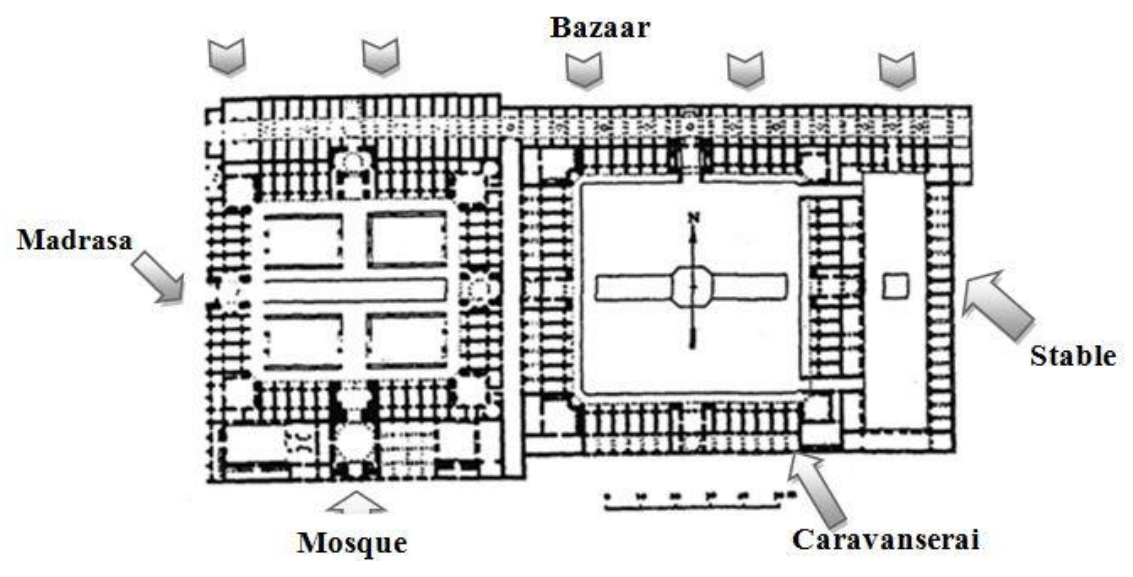

Fig 4. Chahār Bāgh complex plan

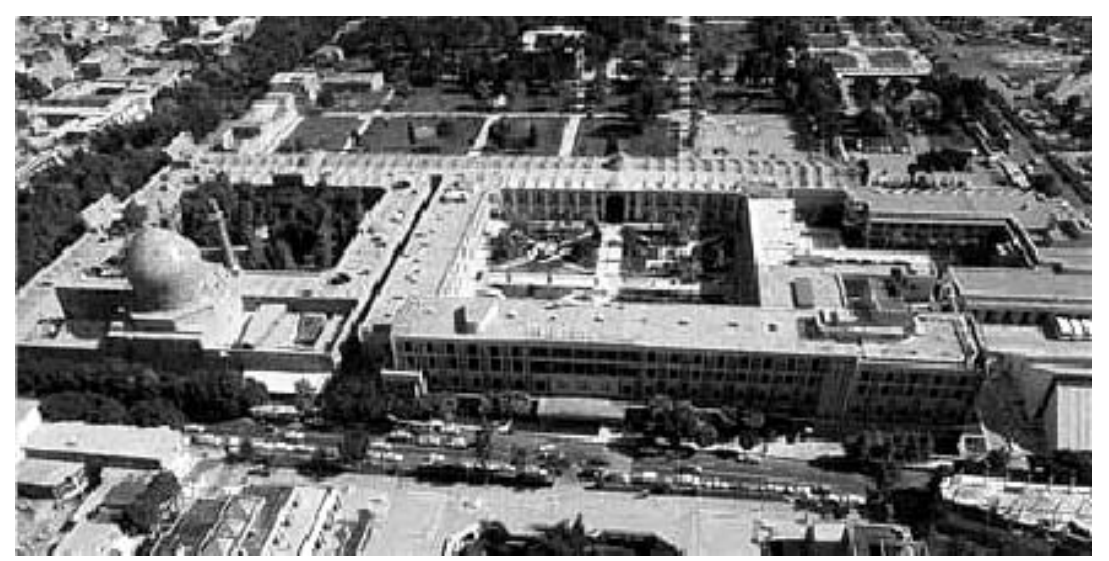

Fig. 5. A sky frame from Chahār Bāgh caravanserai which is built in 16-17th as a cultural complex in Isfahan

\subsection{Semi Urban Caravanserai}

These kinds of caravanserais were located in the country side. They were strongly dependent on cities and their facilities. They hosted many travelers, and their facilities were not less magnificent than urban caravanserais. The largest caravanserais in terms of size and numbers, in Iran, can be categorized 
under this type. Materials used and architectural traits in this category are different from other groups. Additional elements such as a bakery and mosque can be found in the semi-urban caravanserai.

\subsection{Rural Caravanserai}

These were mostly located far from cities. Their plan and the materials used were different from urban caravanserais. Rural caravanserais were more fortified when compared with the other types due to their being situated in locations far from access to national defense. The population of travelers using these was not substantial and they were not considered as being crowded. Due to their inappropriate geographical location, these types of caravanserais are not appreciated and therefore have not been conserved and restored.

In the following sections, methods of analyzing the conservation of Safavid caravanserais will be discussed. However, in this regard, the challenges of sustainable development and adaptive reuse of these structures will also be stated.

\section{$5 \quad$ Adaptive Reuse Issues and Consequences}

Preserving the character of caravanserais is a way to sustain cultural heritage in its context. Adaptive reuse acts, in turn, like ecologically sustainable development (Bullen \& Love, 2010). These caravanserais are often weakly managed or left without any consideration, a condition which leads the structure in a state of deterioration. Increasing pressure from conservationists for preserving national heritage and a growing interest in sustainability has made adaptive reuse as one of the common methods of preserving historical buildings (Yıldırım \& Turan, 2012). The most significant part of the caravanserai conservation movement would be the recycling of historic properties by adapting and using them differently from the function which they originally served. One of the reasons for adapting and reusing buildings of historic value is that they can contribute to the glory of our heritage and open a link to the past (Pimonsathean, 2002). An adaptive reuse project assists to extend the life of historical buildings by altering their function based on contemporary requirements (Rodrigo-Cervantes, 2006). In conservation activities, sustainability would be the continued use of the heritage property in a logical way, adapting current requirements and extending the life of them (Wang \& Zeng, 2010). Additionally, the sustainable adaptive reuse of caravanserais passes the value of these historical structures to future generations; and also promotes the culture and economy of the area by encouraging tourists (Landorf, 2009).

The desirable conclusion of sustainability is the managing of resources in a way that provides social, economic and artistic requirements (Doratli, 2005). Nowadays, there is an increasing demand for places of leisure and entertainment to attract tourism industries all around the world, thus, based on the location and the size of the buildings, adaptive reuse alternative such as restaurants and hotels would be the best option for Safavid caravanserais.

Wang (1997), argued that new uses must be linked to three sorts of activities: cultural tourism, lodging and commerce. Nevertheless, by converting Safavid urban and semi-urban caravanserais to a hotel-restaurant, besides conserving those historical valuable treasures, they can also cover demands such as economic and cultural by reminding visitors about the historic area and their original use (Eley \& Worthington, 1984). In terms of the current condition of caravanserais, the government has not undertaken sufficient supervision of the buildings and unfortunately several of them have been misused as depots (warehouses), and this use can be as harmful for them as if they were abandoned. This issue will be discussed in the following sections. 


\subsection{The Development Process}

Historical buildings which are in a good condition can provide economical and suitable premises for commercial and social purposes (Murtagh, 2005). Cultural attractiveness, good location and the experience of staying in an old-fashion caravanserai in the $21^{\text {st }}$ century gives several reasons for developers to convert and renovate abandoned Safavid caravanserais for commercial purposes such as hotels, restaurants as well as for social purposes such as cultural centers. These conservation projects can involve different types of developers, consisting of: local authorities, private developers and the central government. Most of the creativity for reusing historical buildings comes from private investors (Peerapun, 2012). However, private developers may be apathetic to the value and genuineness of historical buildings (Murtagh, 2005). Local authorities can improve the chances for altering abandoned buildings into commercial units by providing short-term leases. More importantly, local authorities play a significant role in terms of conserving those buildings that are not attractive to private sectors due to their building condition or the location of historic property (Wan Ismail, 2012).

\subsection{Reuse Alternatives and Constraints}

The first step in any adaptive reuse approach in sustainable conservation is to determine the location and spatial needs of the referred project fits with the existing building. The organizational strategy should distinguish whether a specific use is compatible or not (Bullen, 2007). The analysis of urban and semi-urban Safavid caravanserais determined that the best decision to make for adaptive reuse projects as a sustainable development plan for those historical sites would be to return them back their traditional function which was hosting travelers. The new function can satisfy both the local authority and the private sector in terms of socio-cultural and commercial purposes. The caravanserais can be reused as hotel-restaurants due to the appropriate size of the buildings and their architectural patterns.

\subsection{Challenges in Sustainable Development of Caravanserais}

The adaptive reuse implementation must be approached in two ways: most proper reuse and wellmatched reuse. Most of the well-matched adaptive reuse projects are commercially viable. However, they do not make any considerable contribution to a caravanserais' heritage.

Private investors, local authority and governmental involvement play major roles in the sustainable development of a historical site (Yung \& Chan, 2012). According to Rodrigo-Cervantes (2006), adaptive reuse of caravanserais by a private entrepreneur to restaurants, hotels or hotel-restaurants must make ample profits to cover restoration and maintenance costs; otherwise, the government must be involved or cooperate in the maintenance of the building.

In other words, in spite of enabling valuable social advantages to the community by reusing caravanserais as a cultural center, such adaptations do not generate sufficient income to cover maintenance and restoration costs. This kind of reuse, for instance, the development of socio-cultural centers, is normally initiated by the central or local government to address the issues of a heritage building with new establishment and public services. Governmental involvement is considered as a main reason in achieving sustainable development (Pereira Roders \& van Oers, 2011). 


\section{The Assessment of Well-Matched Reuse}

Tourist numbers, tourists' requirements and the potential tourist market are important considerations in the preparation of a management policy in any kind of adaptive reuse projects (Bullen \& Love, 2010). Some of the Safavid caravanserais were chosen to serve as hotel-restaurants, for instance, Madar Shah Caravanserai in Isfahan. In the adaptive reuse of a historic structure for a hotel-restaurant, spaces for guest rooms, lobby, dining area, cooking and laundry facilities are all needed.

Apart from the importance of location, there are other issues which should be addressed when considering well-matched reuse. Compatibility is understood as a reuse criterion which will not damage a place or its cultural significance (Doratli, 2005; Landorf, 2009; Rodrigo-Cervantes, 2006; Wang \& Zeng, 2010). However, to meet these demands, additional necessary spaces must be created within the historical structure. Piping systems for bathrooms, the restaurant's kitchen and other spaces all required alterations in the structure that caused inevitable damage to the ceilings, grounds and walls.

\section{Adapted Reused Caravanserais}

Four adaptive reused historical Safavid caravanserais were selected (Table 1) based on their new functions. The caravanserais were selected from urban and semi-urban groups of caravanserais. They mostly were converted and adapted by local authorities or private investors. Hotel-restaurants, museums, culture centers and rehabilitation centers for addicted people are the adaptive reuse projects that have been done on Safavid caravanserais. According to Andaroodi et al. (2006), there are about 50 urban and semi-urban caravanserais that still possess a great structural condition which must be conserved in terms of sustainable development criteria.

\section{Conclusion}

Caravansaries have been among the most viable elements of Islamic architecture over the centuries. Numerous types of these gigantic structures were built according to local needs. This study details a categorization of caravansaries based on their geographical location; furthermore, also patterns of construction were considered and finally a classification according to urbanization scope to assist decision makers in selecting the most appropriate option in adaptive reuse projects has been introduced. In addition, adaptive reuse of this structure and the challenges encountered by historical areas has been discussed with the target of developing a clear design for potential projects. In this study an attempt has been made to recognize a list of fundamental elements which contribute to the importance of the traditional heritage by preserving of national values. The current study investigated the design approaches which can be used to maximize the cultural consequences for future sustainability. Despite, preserving heritage values, the adaptive reuse of historical structures can also develop sustainability.

The historical Safavid caravanserais have been adaptively reused as a way of preserving and developing the buildings due to structural, financial, functional, cultural and social archaism. This reuse will decrease damage to these particular old buildings which have remained since the Safavid era and provide sustainability for their cultural and historical values. The most compatible and appropriate reuse of several Safavid caravanserais was evaluated. It was perceived that well-matched reuse takes commercially viable activities and provides a sustainable development for the future of the buildings by inviting tourists to the areas. 
In the most adaptive reuse projects, the designer must add several spaces to the structure since, the old structure patterns are not able to cover all the new functional requirements. Nevertheless, the income of adaptive projects will not cover the cost of restoration and maintenance of the Safavid caravanserais if they are converted to a kind of cultural center and they will need governmental support. The findings in this research can be used for potential adaptive reuse projects in which architects can amalgamate the architectural elements used in the Safavid era to be innovative reused.

Table 1 Example of Adapted Reused Safavid Caravanserais and the Plans

Shah Abbasi Caravanserai, semi-urban,
located 38km east of the Karaj City. The
caravanserai is adaptively reused as an
agricultural college, and it is presently in
the possession of the Ministry of
agriculture.The rehabilitation project was
done in the Pahlavi era around 1950 but
after The Islamic revolution in Iran (1997),
it was prepared for new use. Reused by the
central government
Shah Abbasi Caravanserai in Neyshabour
Urban caravanserai, built between 1550-
1570 by the order of Shah Tahmasp I. This
caravanserai temporarily served as the
gendarmerie headquarter of Neyshabour till
1996 and was restored and adaptive reused
again in 2001. Today this building houses
the Museum of Neyshabour.
Reused by the local Authority




\section{References}

Abisaab, Rula Jurdi. (2004). Converting Persia: Religion and Power in the Safavid Empire (Vol. 1): IB Tauris.

Andaroodi, E, Andres, F, Einifar, A, Lebigre, P, \& Kando, N. (2006). Ontology-based shape-grammar schema for classification of caravanserais: a specific corpus of Iranian Safavid and Ghajar open, onroute samples. Journal of Cultural Heritage, 7(4), 312-328.

Babayan, Kathryn. (1994). The Safavid synthesis: from Qizilbash Islam to imamite Shi'ism. Iranian Studies, 27(1-4), 135-161.

Boulnois, Luce. (2004). Silk road: monks, warriors \& merchants on the Silk Road: WW Norton \& Co Inc.

Bullen, Peter A. (2007). Adaptive reuse and sustainability of commercial buildings. Facilities, 25(1/2), 20-31.

Bullen, Peter A, \& Love, Peter ED. (2010). The rhetoric of adaptive reuse or reality of demolition: Views from the field. Cities, 27(4), 215-224.

Doratli, Naciye. (2005). Revitalizing historic urban quarters: A model for determining the most relevant strategic approach. European Planning Studies, 13(5), 749-772.

Eley, Peter, \& Worthington, John. (1984). Industrial rehabilitation. The use of redundant buildings for small enterprises. New York: The architectural press.

Haji, GHASEMI K. (2007). Safavid Architecture in Iran. SOFFEH SPRING-SUMMER, 16(44), 88.

Hillenbrand, Robert. (1994). Islamic architecture: Form, function, and meaning: Columbia University Press.

Kianmehr, Ghobad, \& Taghvanejad, Bahareh. (2011). The comparative study of chaharbagh school of esfahan tile inscriptions and the beliefs in safavid era. Journal of Historical Researches (UNIVERSITY OF ISFAHAN) 7(14), p. 35-49.

Landorf, Christine. (2009). Managing for sustainable tourism: a review of six cultural World Heritage Sites. Journal of Sustainable Tourism, 17(1), 53-70.

Morton, W Brown. (1997). Bayt al-razzaz: The challenge of adaptive use for a vacant mamluk palace in Cairo. International Journal of Heritage Studies, 3(3), 135-143.

Murtagh, William J. (2005). Landscape Preservation, Rural and Small-Town Preservation, Archeology, and Preservation Values in Oral-based Cultures. Keeping Time: The History and Theory of Preservation in America. Third ed. Hoboken, NJ: John Wiley, 107-146.

Pearson, Michael, \& Sullivan, Sharon. (2013). Looking after heritage places: Melbourne Univ. Publishing.

Peerapun, Wannasilpa. (2012). Participatory planning in urban conservation and regeneration: A case study of Amphawa Community. Procedia-Social and Behavioral Sciences, 36, 243-252. 
Pereira Roders, Ana, \& van Oers, Ron. (2011). Editorial: bridging cultural heritage and sustainable development. Journal of Cultural Heritage Management and Sustainable Development, 1(1), 5-14.

Pimonsathean, Yongtanit. (2002). Current issues concerning adaptive re-use in the conservation of urban cultural heritage. Our Heritage, The Development \& Conservation of Old Commercial Quarter in Phuket Town, 8(16), 31-43.

Rabbat, Nasser. (2012). What is Islamic architecture anyway? Journal of Art Historiography(6), 1.

Rodrigo-Cervantes, Norma E. (2006). Urban conservation in mexican colonial cities: the historic centre of Morelia. Designing Sustainable Cities in the Developing World, 5(15), 69-83.

Wan Ismail, WH. (2012). Sustainability of buildings in historic city of Malacca. Asian Journal of Environment-Behaviour Studies, 3(10), 57-69.

Wang, Huey-Jiun, \& Zeng, Zhi-Teng. (2010). A multi-objective decision-making process for reuse selection of historic buildings. Expert Systems with Applications, 37(2), 1241-1249.

Wang, Ning. (1997). Vernacular house as an attraction: illustration from hutong tourism in Beijing. Tourism Management, 18(8), 573-580.

Worthing, Derek, \& Bond, Stephen. (2008). Managing built heritage: John Wiley \& Sons.

Yildırım, Mücahit, \& Turan, Gizem. (2012). Sustainable development in historic areas: Adaptive re-use challenges in traditional houses in Sanliurfa, Turkey. Habitat International, 36(4), 493-503.

Yung, Esther HK, \& Chan, Edwin HW. (2012). Implementation challenges to the adaptive reuse of heritage buildings: Towards the goals of sustainable, low carbon cities. Habitat International, 36(3), $352-361$.

\section{Copyrights}

Copyright for this article is retained by the author (s), with first publication rights granted to the journal.

This is an open-access article distributed under the terms and conditions of the Creative Commons Attribution license (http://creativecommons.org/licenses/by/4.0/). 